\title{
Zoledronic acid increases docetaxel cytotoxicity through pMEK and Mcl-I inhibition in a hormone-sensitive prostate carcinoma cell line Francesco Fabbri ${ }^{1}$, Giovanni Brigliadori ${ }^{1}$, Silvia Carloni ${ }^{1}$, Paola Ulivi ${ }^{1}$, Ivan Vannini ${ }^{1}$, Anna Tesei ${ }^{1}$, Rosella Silvestrini ${ }^{1}$, Dino Amadori ${ }^{2}$ and Wainer Zoli*1
}

\author{
Address: ${ }^{1}$ Biosciences Laboratory, Istituto Scientifico Romagnolo per lo Studio e la Cura dei Tumori (I.R.S.T.), Meldola, Italy and ${ }^{2}$ Department of \\ Medical Oncology, Istituto Scientifico Romagnolo per lo Studio e la Cura dei Tumori (I.R.S.T.), Meldola, Italy \\ Email: Francesco Fabbri - francesco.fabbri@ausl.fo.it; Giovanni Brigliadori - gbrigliadori@ausl.fo.it; Silvia Carloni - silvia.carloni@irst.emr.it; \\ Paola Ulivi - p.ulivi@ausl.fo.it; Ivan Vannini - i.vannini@ausl.fo.it; Anna Tesei - anna.tesei@ausl.fo.it; \\ Rosella Silvestrini - silvestrini@istitutotumori.mi.it; Dino Amadori - segronco@ausl.fo.it; Wainer Zoli* - w.zoli@ausl.fo.it \\ * Corresponding author
}

Published: 8 August 2008

Journal of Translational Medicine 2008, 6:43 doi:10.1 I86/1479-5876-6-43

Received: 22 May 2008

Accepted: 8 August 2008

This article is available from: http://www.translational-medicine.com/content/6/I/43

(C) 2008 Fabbri et al; licensee BioMed Central Ltd.

This is an Open Access article distributed under the terms of the Creative Commons Attribution License (http://creativecommons.org/licenses/by/2.0), which permits unrestricted use, distribution, and reproduction in any medium, provided the original work is properly cited.

\begin{abstract}
Background: In prostate cancer, the identification of drug combinations that could reduce the tumor cell population and rapidly eradicate hormone-resistant cells potentially present would be a remarkable breakthrough in the treatment of this disease.

Methods: The study was performed on a hormone-sensitive prostate cancer cell line (LNCaP) grown in normal or hormone-deprived charcoal-stripped (c.s.) medium. Cell viability and apoptosis were assessed by SRB assay and Annexin-V/TUNEL assays, respectively. Activated caspase-3, p2I, PMEK and MCL-I expression levels were detected by western blotting.

Results: The simultaneous exposure of zoledronic acid [100 $\mu \mathrm{M}]$ and docetaxel $[0.01 \mu \mathrm{M}]$ for I $\mathrm{h}$ followed by treatment with zoledronic acid for 72,96 or $120 \mathrm{~h}$ produced a high synergistic interaction $(R$ index $=5.1)$ with a strong decrease in cell viability. This cytotoxic effect was associated with a high induction of apoptosis in both $\mathrm{LNCaP}$ and in c.s. $\mathrm{LNCaP}$ cells. The induction of apoptosis was paralleled by a decrease in PMEK and Mcl-I expression.

Conclusion: The zoledronic acid-docetaxel combination produced a highly significant synergistic effect on the LNCaP cell line grown in normal or hormone-deprived medium, the principal molecular mechanisms involved being apoptosis and decreased PMEK and Mcl-I expression. This experimentally derived schedule would seem to prevent the selection and amplification of hormone-resistant cell clones and could thus be potentially used alongside standard androgen deprivation therapy in the management of hormone-sensitive prostate carcinoma.
\end{abstract}

\section{Introduction}

The overall incidence of prostate cancer, one of the most common lethal malignancies and the second cause of cancer mortality in males, is gradually increasing in western countries. In the early stages of the disease, surgery, radiotherapy and/or androgen deprivation are the most effective clinical therapies. In particular, hormonal therapy leads to remission which typically lasts from 2 to 3 years. 
However, prostate cancer frequently metastasizes to bone and almost invariably progresses to an androgen-independent state, with a poor prognosis and a median survival that varies from 10 to 20 months [1]. Notwithstanding the introduction of new chemotherapeutic agents, the life expectancy of patients with advanced prostate cancer is still limited. The development of new drugs or the identification of novel drug combinations which could reduce the development of endocrinerefractory cell clones thus remain important goals.

It has been shown that docetaxel (Doc) exerts a potent cytotoxic effect in vitro and considerably prolongs survival in patients with advanced prostate cancer $[2,3]$. At the same time, zoledronic acid ( $\mathrm{Zol}$ ) has proven to be capable of preventing tumor growth in different in vitro models [4] and has shown significant clinical potential for reducing cancer-related bone lesions and inhibiting bone reabsorption [5].

The Ras/Raf/MEK/ERK signalling cascade is one of the most important intracellular pathways controlling cell proliferation, differentiation and cell death, and appears to be involved in prostate cancer drug resistance $[6,7]$. Moreover, in different experimental models, it has been shown that inhibition of at least one of these regulatory proteins may induce apoptosis through the downregulation of the anti-apoptotic protein Mcl-1, a member of the Bcl-2 family $[8,9]$. Mcl-1 is expressed in a fairly high percentage of prostate tumors [10-12], and the inhibition of Ras/Raf/MEK/ERK-mediated signals, and consequently of Mcl-1 expression, could therefore also be a key objective in the treatment of hormone-sensitive prostate cancer cells, as shown by Cavarretta et al [13].

The aim of the present study was to examine the in vitro activity of Zol and low Doc concentrations, alone or in combination, and to explore the molecular mechanisms underlying treatment-related cell proliferation and apoptosis, especially in relation to MEK and Mcl-1 expression. Very low Doc concentrations were chosen so as not to preclude the use of the taxane at conventional doses as second-line treatment in more advanced disease. Moreover, in order to approximate clinical conditions, the study was performed on cells grown in normal or hormonedeprived medium and on the same cell line after pretreatment with the taxane.

\section{Materials and methods Cell culture}

The studies were performed on a hormone-sensitive prostate cancer cell line, LNCaP, obtained from the American Type Culture Collection (Rockville, MD). The cell line was maintained as a monolayer at $37^{\circ} \mathrm{C}$ and subcultured weekly. Culture medium was composed of RPMI 1640 supplemented with $10 \%$ fetal calf serum and $1 \%$ glutamine (Mascia Brunelli s.p.a., Milan, Italy). Cells were used in the exponential growth phase in all the experiments. Depending on the experimental setting, LNCaP cells were seeded in RPMI 1640 medium containing either $10 \%$ fetal calf serum or charcoal-stripped $10 \%$ fetal calf serum. Doc pre-treated LNCaP cells were generated by exposing the cell line to $0.001 \mu \mathrm{M}$ of Doc for $1 \mathrm{~h}$ once a week for one month, which produced cells resistant to this dose of taxane. Thereafter, these cells were maintained in culture medium containing $0.001 \mu \mathrm{M}$ of the taxane.

\section{Drugs}

Docetaxel $\left(\right.$ Taxotere $^{\circledast}$ ), kindly supplied by Aventis Pharma, was solubilized and stored at a concentration of $12.6 \mathrm{mM}$ in $13 \%$ ethanol at $4{ }^{\circ} \mathrm{C}$ and diluted in medium before use. The final concentration of ethanol never exceeded $0.01 \%$ and therefore had no effect on cell growth or viability. Control cells were exposed to the same amount of solvent. Zoledronic acid (Zometa $\left.{ }^{\circledR}\right)$ (Zol), kindly provided by Novartis, was solubilized and stored at a concentration of $25 \mathrm{mM}$ in sterile water at $20^{\circ} \mathrm{C}$ and diluted in medium before use.

\section{Chemosensitivity assay}

Sulforhodamine B (SRB) assay was used according to the method by Skehan et al. [14]. Briefly, cells were collected by trypsinization, counted and plated at a density of 5,000 cells/well in 96-well flat-bottomed microtiter plates (100 $\mu \mathrm{l}$ of cell suspension/well). In the chemosensitivity assay, experiments were run in octuplicate, and each experiment was repeated three times. The optical density (OD) of cells was determined at a wavelength of $540 \mathrm{~nm}$ by a colorimetric plate reader. Growth inhibition and cytocidal effect of drugs were calculated according to the formula reported by Monks et al [15]: [( $\left(\mathrm{OD}_{\text {treated }}-\mathrm{OD}_{\text {zero }}\right) /\left(\mathrm{OD}_{\text {con- }}\right.$ trol $\left.\left.-\mathrm{OD}_{\text {zero }}\right)\right] \times 100 \%$, when $\mathrm{OD}_{\text {treated }}$ is $>$ to $\mathrm{OD}_{\text {zero }}$. If $\mathrm{OD}_{\text {treated }}$ is above $\mathrm{OD}_{\text {zero' }}$ treatment has induced a cytostatic effect, whereas if $\mathrm{OD}_{\text {treated }}$ is below $\mathrm{OD}_{\text {zero' }}$ cell killing has occurred. The $\mathrm{OD}_{\text {zero }}$ depicts the cell number at the moment of drug addition, the $\mathrm{OD}_{\text {control }}$ reflects the cell number in untreated wells and the $\mathrm{OD}_{\text {treated }}$ reflects the cell number in treated wells on the day of the assay.

\section{Single drug exposure}

Cells were exposed for $1 \mathrm{~h}$ to $0.001-, 0.01-, 0.1$ - or $1.0-\mu \mathrm{M}$ concentrations of Doc followed by a 72-, 96- or 120-h culture in drug-free medium. Zol treatment consisted of continuous exposure of $50-, 100-$, or $200-\mu \mathrm{M}$ concentrations for 72,96 or $120 \mathrm{~h}$.

\section{Drug combinations}

The following treatment schedules were utilized (Table 1): 
Table I: Treatment schedules in LNCaP hormone-sensitive cell line

Doc* + Zol (100 $\mu$ M) I h $\rightarrow$ Zol (100 $\mu$ M) 72, 96, I20 h

Zol $(100 \mu \mathrm{M}) 72,96,120 \mathrm{~h} \rightarrow$ Doc* $^{*}$ Zol $(100 \mu \mathrm{M})$ I h

$* 0.001,0.01$, or $0.1 \mu \mathrm{M}$

1. Simultaneous exposure to Zol $100 \mu \mathrm{M}$ and Doc 0.001, 0.01 or $0.1 \mu \mathrm{M}$ for $1 \mathrm{~h}$ followed by Zol exposure for 72, 96 or $120 \mathrm{~h}$;

2. Continuous exposure to Zol for 72,96 or $120 \mathrm{~h}$ followed by simultaneous exposure to Zol $100 \mu \mathrm{M}$ and Doc $0.001,0.01$ or $0.1 \mu \mathrm{M}$ for $1 \mathrm{~h}$.

Cytotoxic activity was evaluated immediately after the end of drug exposure.

\section{Drug interaction analysis}

Kern et al.'s method [16], subsequently modified by Romanelli et al. [17], was used to evaluate the interaction between drugs. In brief, the expected cell survival $\left(S_{\text {exp }}\right.$ defined as the product of the survival observed with drug A alone and the survival observed with drug $B$ alone) and the observed cell survival $\left(S_{\text {obs }}\right)$ for the combination of A and B were used to construct an R index (RI): RI $=S_{\text {exp }} /$ $S_{\text {obs }}$. An RI of $\leq 0.5$ indicated the absence of synergism or antagonism. Synergism was defined as any value of RI > 1.5. In all experiments, the standard deviation did not exceed $10 \%$. Therefore, only differences of $\geq 0.5$ from unity in RI values were considered significant.

\section{Flow cytometry}

After different drug exposures, medium was removed and cells were detached from the flasks by trypsin treatment, washed twice with PBS and stained according to the different methods specified below. Flow cytometric analysis was performed using a FACS Canto flow cytometer (Becton Dickinson, San Diego, CA). Data acquisition and analysis were performed using FACSDiva software (Becton Dickinson). Samples were run in triplicate and 10,000 events were collected for each replica. Data were the average of three experiments, with errors under $5 \%$.

\section{Apoptosis}

TUNEL assay

Cells were fixed in 1\% paraformaldehyde in PBS on ice for $15 \mathrm{~min}$, suspended in ice cold ethanol (70\%) and stored overnight at $-20^{\circ} \mathrm{C}$. Cells were then washed twice in PBS and resuspended in PBS containing $0.1 \%$ Triton X-100 for $5 \mathrm{~min}$ at $4^{\circ} \mathrm{C}$. Thereafter, samples were incubated in $50 \mu \mathrm{l}$ of solution containing TdT and FITC-conjugated dUTP deoxynucleotides 1:1 (Roche Diagnostic GmbH, Mannheim, Germany) in a humidified atmosphere for $90 \mathrm{~min}$ at $37^{\circ} \mathrm{C}$ in the dark, washed in PBS, counterstained with propidium iodide $(2.5 \mu \mathrm{g} / \mathrm{ml}, \mathrm{MP}$ Biomedicals, Verona, Italy) and RNAse (10 Kunits/ml, Sigma Aldrich, Milan, Italy) for $30 \mathrm{~min}$ at $4{ }^{\circ} \mathrm{C}$ in the dark and analyzed by flow cytometry.

\section{Annexin-V assay}

Cells were harvested, washed once in PBS and incubated with $10 \mu \mathrm{l} / \mathrm{ml}$ Annexin V-FITC in binding buffer (Bender MedSystems, Vienna, Austria) for $15 \mathrm{~min}$ at $37^{\circ} \mathrm{C}$ in a humidified atmosphere in the dark. Cells were then washed in PBS and suspended in binding buffer. Immediately before flow cytometric analysis, propidium iodide was added to a final concentration of $5 \mu \mathrm{g} / \mathrm{ml}$ to distinguish between total apoptotic cells (Ann-V + and PI - or +) and necrotic cells (Ann-V - and PI +). For each sample, 15,000 events were recorded.

\section{Western blot}

Cells were lysed and proteins were denaturated, separated on $10 \%$ SDS-polyacrylamide gel and electroblotted onto Hybond-C extra membrane (Amersham Pharmacia Biotech, Cologna Monzese, Italy). The membrane was stained with Ponceau S (Sigma Aldrich) to verify equal amounts of sample loading and then incubated for $2 \mathrm{~h}$ at room temperature with T-PBS 5\% non fat dry milk. The membrane was probed overnight at $4{ }^{\circ} \mathrm{C}$ with the antibody, after which horseradish peroxidise-conjugated secondary antibody diluted 1:1,000 (Dako Corporation, Glostrup, Denmark) was added. Bound antibodies were detected by enhanced chemiluminescence (ECL) using an ECL kit (Amersham Pharmacia Biotech). The following primary antibodies were used: p21 (monoclonal antibody, dilution 1:250) (BioOptica, Milan, Italy), caspase-3 (polyclonal antibody, dilution 1:500) (Cell Signalling Technology, Inc., Beverly, MA), pMEK (monoclonal antibody, dilution 1:1000) (Cell Signalling Technology), actin (polyclonal antibody, dilution 1:5000) (Sigma Aldrich) and Mcl-1 (monoclonal antibody, dilution 1:100) (BD, Pharmingen, San Diego, CA). Quantitative analysis was carried out with Quantiscan software (Biosoft, Cambridge, UK).

\section{Morphological investigation}

After different drug exposures, medium was removed, cells were detached from the flasks by trypsin treatment, washed twice with PBS, fixed in ethanol (70\%), stained with the cell-permeable dyes 4',6-DAPI (Molecular Probes, Leiden, The Netherlands) and SRB (Sigma Aldrich) and then examined by fluorescence photomicroscope (Zeiss, Axioscope 40) to visualize chromatin condensation and/or fragmentation typical of apoptotic cells.

\section{Statistical analysis}

Differences between treatments, in terms of dose response and apoptosis, were determined using the Student's t test 
for unpaired observations. $\mathrm{p}<0.05$ was considered significant.

\section{Results \\ Single drug activity}

Cytotoxicity was assessed at scalar drug concentrations and after different exposure times. Doc produced a strong cytotoxic effect after all treatment schedules and the 50\% lethal concentration $\left(\mathrm{LC}_{50}\right)$ was reached $120 \mathrm{~h}$ after a 1-h exposure to a $0.057-\mu \mathrm{M}$ concentration. Although Zol treatment also produced a cytotoxic effect, $\mathrm{LC}_{50}$ was only reached after a 120-h exposure to a concentration of $176.70 \mu \mathrm{M}$ (Figure 1).

\section{Drug combinations}

After preliminary experiments, the efficacy of two different drug combination schedules was further explored
(Table 1). Simultaneous exposure to Zol $(100 \mu \mathrm{M})$ and Doc $(0.001 \mu \mathrm{M})$ for $1 \mathrm{~h}$ followed by Zol exposure for 72 , 96 or $120 \mathrm{~h}$ produced a strong cytocidal effect, and the $\mathrm{LC}_{50}$ was reached after $96 \mathrm{~h}$ of continuous exposure (Figure $2 \mathrm{~A}$ ). At the higher Doc concentrations (0.01 and 0.1 $\mu \mathrm{M})$, cytocidal activity further increased, exceeding the $\mathrm{LC}_{90}$ (Figure $2 \mathrm{~B}-\mathrm{C}$ ). Starting from a $0.01-\mu \mathrm{M}$ Doc concentration, the combination schedule produced an important synergistic effect which yielded an $\mathrm{R}$ index of 5.1. The highest Doc concentration $(0.1 \mu \mathrm{M})$ did not produce any further significant synergistic interactions and was therefore not tested in subsequent experiments. The schedule consisting of Zol followed by simultaneous exposure to Zol and Doc induced only a very weak additive effect with respect to Zol used alone (Figure $2 \mathrm{~A}-\mathrm{B}-\mathrm{C}$ ).
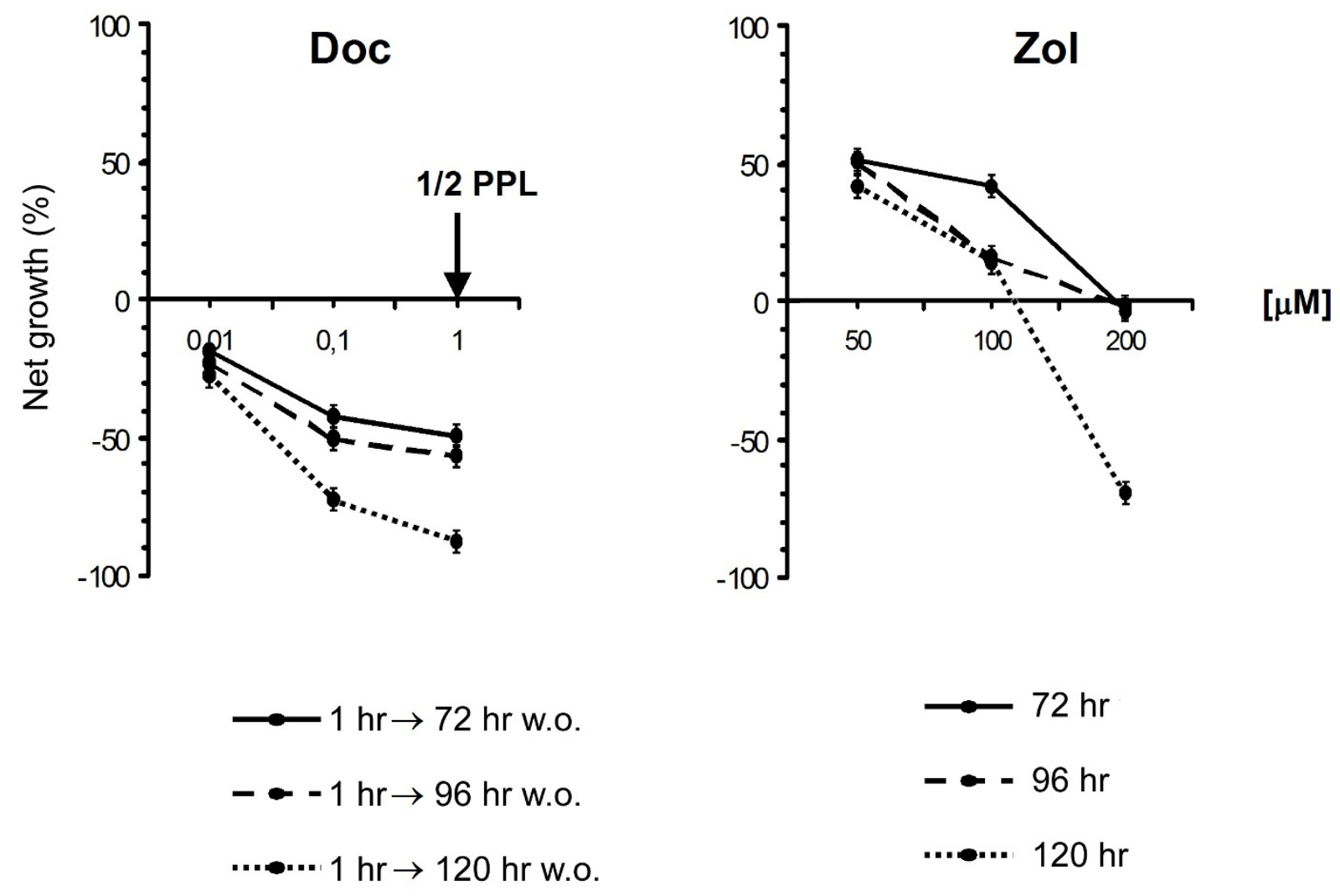

\section{Figure I}

Dose effect curves of Doc and Zol in LNCaP hormone-sensitive cell line. Net cell growth was measured by SRB assay at the end of different washout (w.o.) times after a I-h exposure to scalar concentrations of Doc (0.0 I, 0.I, I.0 $\mu$ M - left diagram) and after continuous exposure to scalar concentrations of Zol (50, 100, $200 \mu \mathrm{M}$ - right diagram). Error bars represent the mean standard deviation. 
A

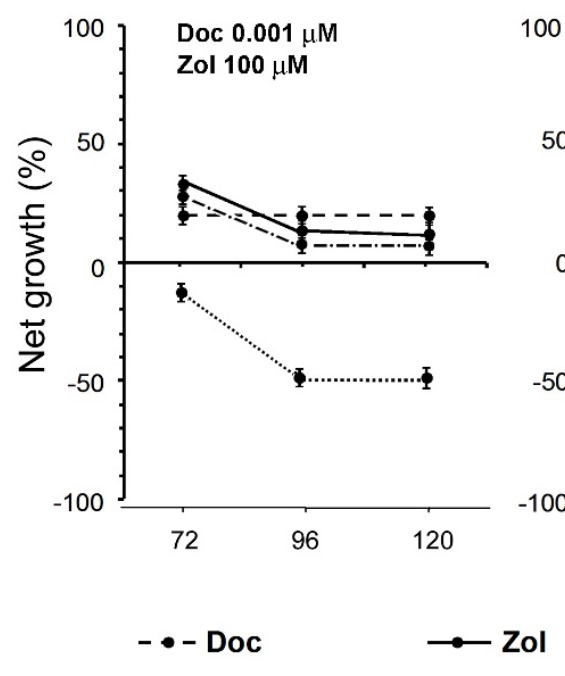

B

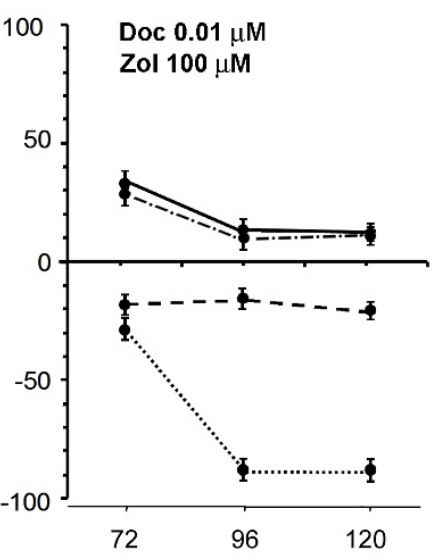

$\cdots \cdot \cdots \cdot$ Doc + Zol $\rightarrow$ Zol
C

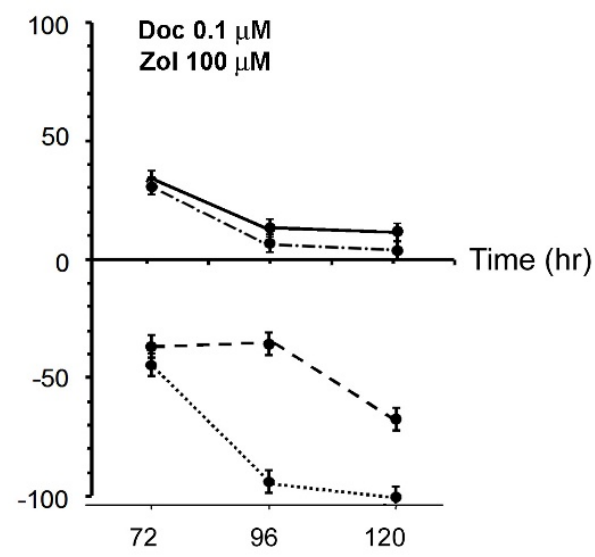

-••-- Zol $\rightarrow$ Zol + Doc

Figure 2

Comparison between different drug schedules. Dashed line: activity observed 72,96 and $120 \mathrm{~h}$ after a I-h exposure to low Doc concentrations $(0.001,0.01$ and $0.1 \mu \mathrm{M}$ in diagrams $A, B$ and $C$, respectively). Solid line: activity detected after a $72-$-, 96- and I20-h continuous exposure to Zol $100 \mu \mathrm{M}$. Dotted line: activity observed after a I-h concomitant exposure to Zol 100 $\mu \mathrm{M}$ and low Doc concentrations $(0.00 \mathrm{I}, 0.0 \mathrm{I}$ and $0.1 \mu \mathrm{M}$, in diagrams $\mathrm{A}, \mathrm{B}$ and $\mathrm{C}$, respectively) followed by prolonged exposure to Zol $100 \mu \mathrm{M}$. Dash-dotted line: activity observed after prolonged exposure to Zol $100 \mu \mathrm{M}$ followed by a I-h concomitant exposure to Zol $100 \mu \mathrm{M}$ and low Doc concentrations $(0.00 \mathrm{I}, 0.0 \mathrm{I}$ and $0.1 \mu \mathrm{M}$, in diagrams $\mathrm{A}, \mathrm{B}$ and $\mathrm{C}$, respectively). Error bars represent the mean standard deviation.

\section{Apoptosis}

Assessment of apoptosis by TUNEL assay showed that low-dose Doc induced a small percentage of apoptotic cells which never exceeded $10 \%$ at either the longest exposure time $(120 \mathrm{~h})$ or the highest drug concentration $(0.01$ $\mu \mathrm{M})$. Conversely, Zol $100 \mu \mathrm{M}$ induced a statistically significant, exposure time-dependent increment in apoptotic cells between 4- and 20-fold higher than that detected in untreated cells (Table 2).

The schedule using Doc $0.001 \mu \mathrm{M}$ did not produce a significantly higher number of apoptotic cells with respect to treatment with Zol alone. Conversely, the drug combination using a $0.01-\mu \mathrm{M}$ Doc concentration induced a significant increase in the percentage of TUNEL-positive cells ranging from $40 \%$ at $72 \mathrm{~h}$ to $66 \%$ at $120 \mathrm{~h}$ (Table 2 ). Similar results for the TUNEL assay were observed regardless of the type of medium used and were confirmed by morphological evaluation of cells exposed to the aforementioned treatments (Figure 3). Apoptosis evaluation by
ANN-V assay in the LNCaP line grown in different hormone culture conditions showed that the number of apoptotic cells progressively increased after Doc, Zol or combined drug exposure from about 20 to $70 \%$ at any of the times considered, and once again this increase was

Table 2: Apoptotic cells (\%) in LNCaP line by TUNEL assay

\begin{tabular}{|c|c|c|c|c|}
\hline & & \multicolumn{3}{|c|}{ Observation time } \\
\hline & & $72 \mathrm{~h}$ & $96 \mathrm{~h}$ & $120 \mathrm{~h}$ \\
\hline Control & & 1.5 & 2.0 & 2.0 \\
\hline \multirow[t]{2}{*}{ Doc I h } & $0.001 \mu \mathrm{M}$ & 1.3 & I.I & 4.8 \\
\hline & $0.01 \mu \mathrm{M}$ & 2.5 & 3.8 & 9.2 \\
\hline $\begin{array}{l}\text { Zol continuous } \\
\text { exposure }\end{array}$ & $100 \mu \mathrm{M}$ & 4.9 & 11.5 & $37.8 *$ \\
\hline \multicolumn{2}{|c|}{$\begin{array}{l}\text { Doc }(0.00 \mathrm{I} \mu \mathrm{M})+ \\
\text { Zol }(100 \mu \mathrm{M}) \mathrm{I} \mathrm{h} \rightarrow \text { Zol }(100 \mu \mathrm{M})\end{array}$} & I I.2 & 20.1 & $30.8 *$ \\
\hline \multicolumn{2}{|c|}{$\begin{array}{l}\text { Doc }(0.01 \mu \mathrm{M})+ \\
\text { Zol }(100 \mu \mathrm{M}) \mathrm{I} \mathrm{h} \rightarrow \text { Zol }(100 \mu \mathrm{M})\end{array}$} & 40.2 & 41.6 & $66.5 *$ \\
\hline
\end{tabular}

*Significance at $\mathrm{p}<0.05$ by $\mathrm{t}$ test 

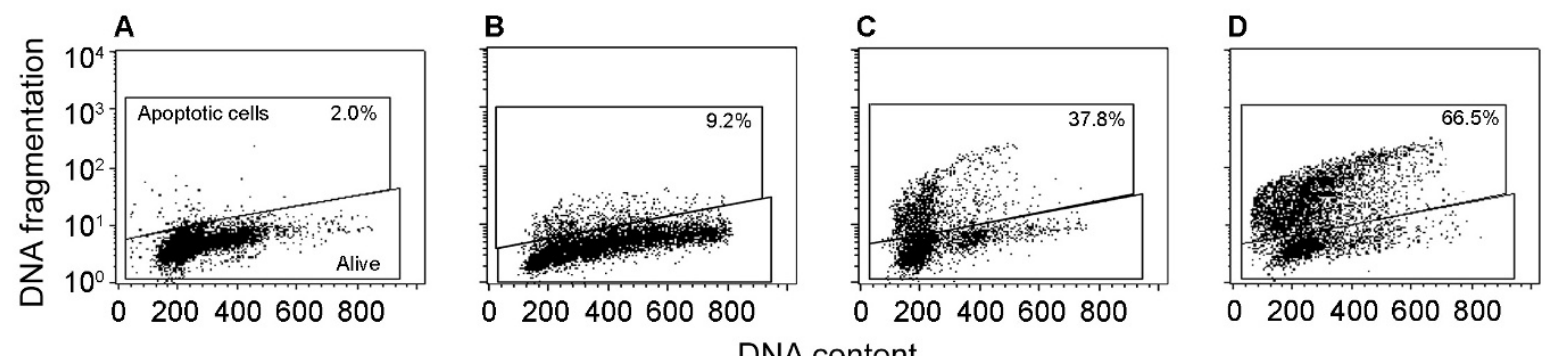

DNA content
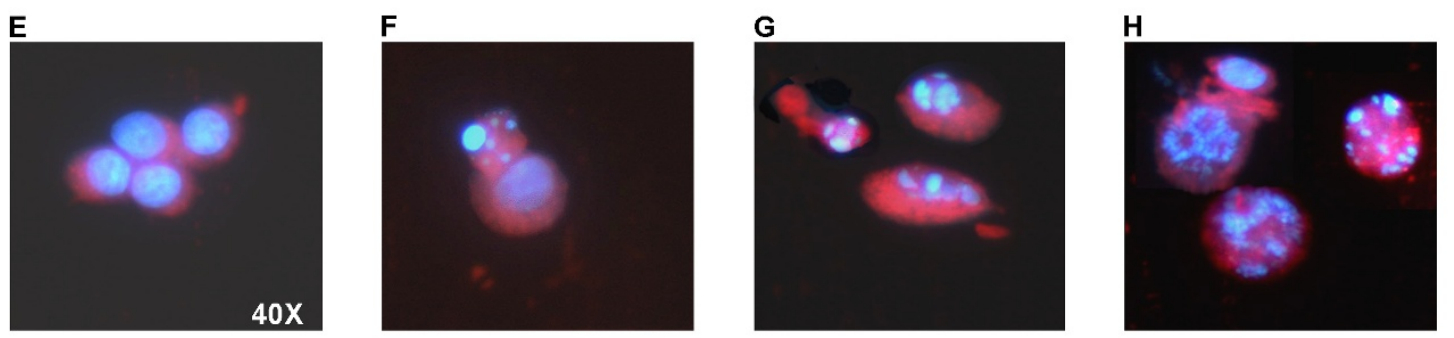

\section{Figure 3}

Representative cytofluorimetric dot plots of one of the TUNEL experiments and characteristic morphologic images of apoptotic cells observed after drug exposure. $A$ and $E$, untreated cells; $B$ and $F$, after a I-h exposure to Doc $0.01 \mu \mathrm{M}$ followed by a I20-h w.o.; C and G, after a I20-h continuous exposure to Zol I00 $\mu \mathrm{M}$; D and H, after exposure to the combination Doc + Zol $\rightarrow$ Zol.

similar regardless of the type of medium used (Figure 4). The number of apoptotic cells also showed a similar trend in taxane pre-treated LNCaP cells, but reached a significantly higher level (90\%) after the drug sequence exposures.

\section{Interference in apoptosis- and cell proliferation-related markers}

The expression of the pMEK protein kinase was progressively downregulated from 2 - to 10 -fold by the bisphosphonate and completely disappeared after $96 \mathrm{~h}$ of continuous exposure to the drug (Figure 5). Conversely, a 1 -h treatment with Doc induced a 7 -fold increase in pMEK expression after $48 \mathrm{~h}$, which then progressively decreased and disappeared at $120 \mathrm{~h}$. After the synergic drug sequence exposure, a 4-fold increase in pMEK expression with respect to the control was also observed, which, however, completely disappeared after $96 \mathrm{~h}$.

The expression of Mcl-1 protein was downregulated up to 3- and 5-fold by Zol and Doc, respectively. However, whilst these inhibiting effects persisted in the presence of the bisphosphonate for up to $120 \mathrm{~h}$, a 1.5-fold upregulation of Mcl-1 was observed after treatment with the taxane with respect to the control, showing a complementary profile to that of pMEK. The drug sequence exposure not only prevented the late upregulation observed after treatment with Doc, but also induced the total disappearance of $\mathrm{Mcl}-1$ protein expression. No important variations in pMEK or Mcl-1 expression with respect to the control were observed after exposure times of $<48$ h (data not shown).

Whilst p21 expression was not affected by exposure to Zol, it increased up to 2-fold after Doc treatment. Conversely, p21 expression showed a > 1.5-fold decrease after $120 \mathrm{~h}$ of the combination treatment.

The active form of caspase- 3 was detected around $120 \mathrm{~h}$ after bisphosphonate exposure, whereas it was observed earlier and at lower levels after Doc treatment. Conversely, after the drug sequence exposure, its expression profile was quantitatively and qualitatively the sum of the expression detected after exposure to the single drugs.

All the aforementioned alterations in marker expression were observed regardless of the type of medium used.

\section{Discussion}

In the present study, docetaxel and zoledronic acid induced noteworthy cytostatic and cytocidal effects on the hormone-sensitive prostate cancer cell line, LNCaP, in agreement with results from previous papers [18-21]. In 


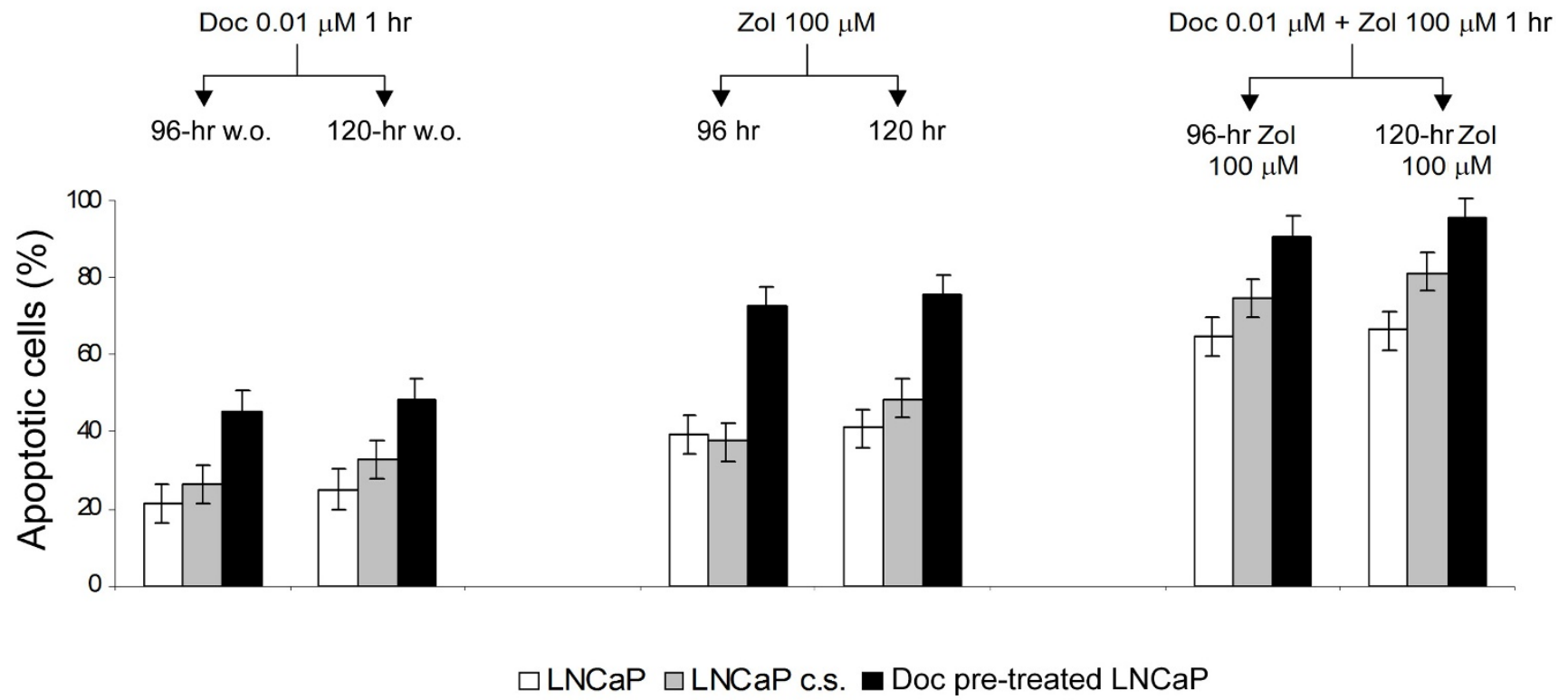

Figure 4

Apoptotic cells (\%) measured by Ann-V assay in LNCaP line grown in normal medium (white bars), charcoalstripped (c.s.) hormone-deprived medium (grey bars) and normal medium after taxane pre-treatment (black bars). Cells were analyzed after a I-h exposure to Doc $0.01 \mu \mathrm{M}$ followed by a 96- or I20-h w.o. (left histogram bars), after a 96- or I20-h continuous exposure to Zol $100 \mu \mathrm{M}$ (center histogram bars), and after exposure to the Doc-Zol combination (right histogram bars). The percentage of apoptosis in untreated cells never exceeded 10\%. Error bars represent the mean standard deviation.

particular, the highest inhibition of cell proliferation was observed after Doc exposure and was already evident at concentrations 200-fold lower than the plasma peak level.

Interestingly, among the different drug schedules tested, a short, concomitant exposure to Zol and low Doc concentrations followed by a prolonged Zol exposure proved to be the most effective combination. In particular, this schedule produced an elevated synergistic interaction and a strong decrease in cell viability. Conversely, the combination of Zol followed by simultaneous exposure to Zol and Doc induced only a weak additive effect, which may be a result of Zol triggering apoptosis directly in the G0/1 phase and leaving virtually no cells in G2/M, which is known to be Doc's main target.

Drug concentrations and exposure times utilized in our study were chosen on the basis of both literature data [1928] and results from preclinical investigations carried out in our laboratory $[29,30]$ to identify dosages and timing that would have a significant impact on hormone-sensitive prostate cancer cell survival. Our results suggest that this therapeutic approach could be useful as first-line treatment of hormone-sensitive prostate cancer. Furthermore, notwithstanding the obvious differences between our experimental system and a clinical setting of metastatic prostate cancer, the cell model (LNCaP) we used was originally isolated from a metastatic lymph node [31] and can therefore be considered fairly representative of hormone-sensitive metastatic disease. This would seem to suggest the potential clinical applicability of our results for patients with hormone-sensitive metastatic prostate cancer.

The two drugs induced mainly independent effects on apoptosis and cell proliferation. In fact, low Doc concentrations produced a high cytostatic effect, probably linked to cell cycle arrest, but induced a relatively low fraction of apoptotic cells, whereas Zol exerted a predominantly high cytotoxic and pro-apoptotic effect on the cell line. Despite this apparent incongruence, sequential exposure to the two-drug sequence caused a considerable increment in the percentage of apoptotic cells, reaching values between 2 and 6-fold higher than those observed after single drug 


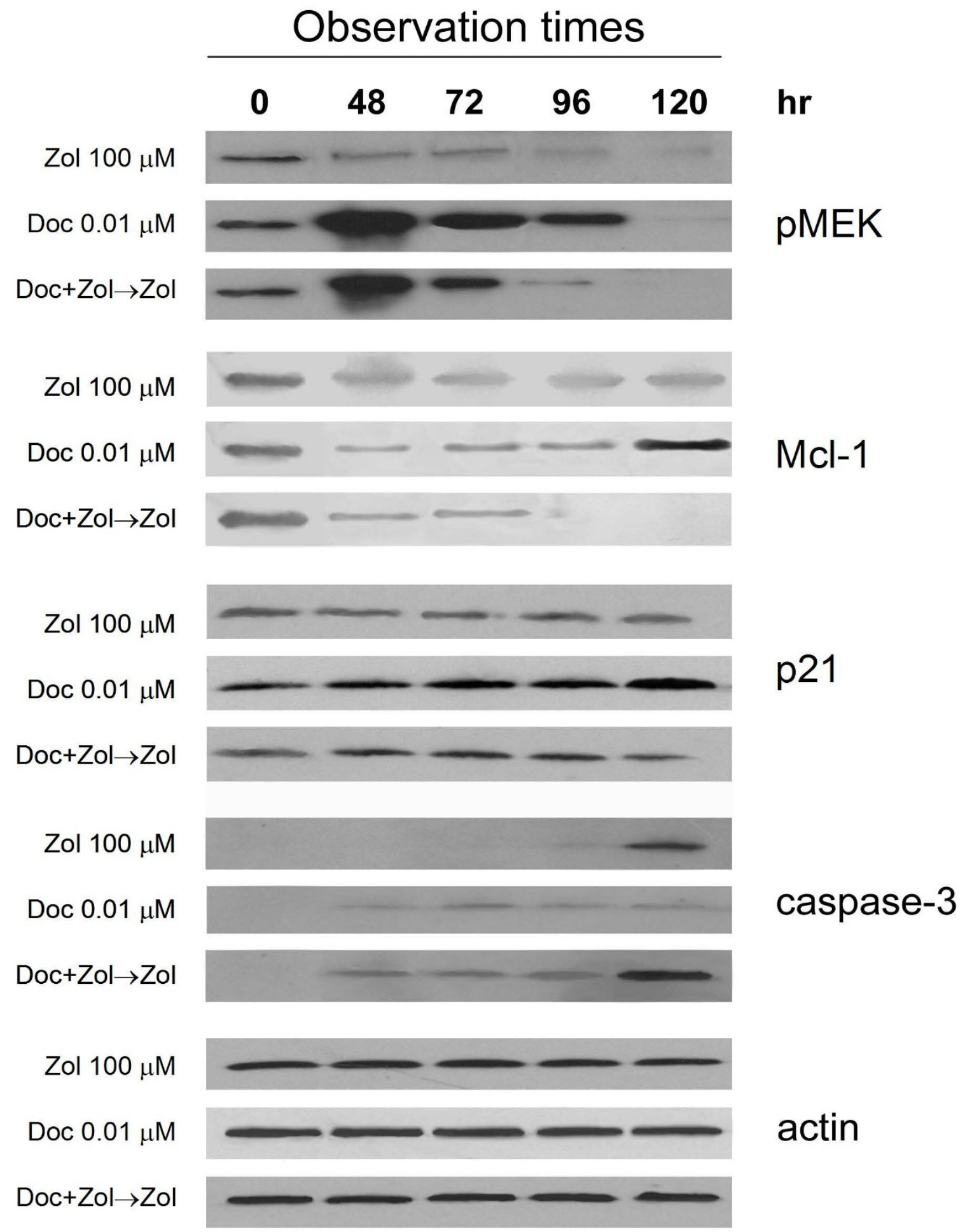

\section{Figure 5}

PMEK, Mcl-I, p2I and active caspase-3 protein expression observed by western blot after exposure to different drug schedules. In the combination schedule, drug concentrations were the same as those used for single drug exposures. 
exposure, and further confirming the synergistic cytotoxic effect.

We also evaluated drug activity in cells grown in hormone-deprived medium, thus approximating the standard clinical setting in which prostate cancer patients are treated with androgen deprivation therapy. Under these conditions, the percentage of apoptotic cells after exposure to various treatment schedules was similar to that observed in cells grown in normal medium, indicating that a hormone-deprived environment should not, in theory, compromise the activity of chemotherapy. Moreover, single drug or combination activity was maintained in LNCaP cells pre-treated with low Doc concentrations. Our results therefore suggest that treatment with low taxane doses would not preclude response to conventional docetaxel doses used in the clinical treatment of advanced, hormone-refractory tumors.

Cell reactions to single drugs and their association were paralleled by alterations in the expression of proteins involved in cell proliferation and apoptosis. Zol treatment generally induced a prolonged downregulation of both pMEK, known to be involved in cell proliferation signal transduction [8], and the anti-apoptotic protein, Mcl-1 [9]. Furthermore, the bisphosphonate did not cause any major changes in p21 expression, known to be related to cell cycle arrest and Doc resistance [32], and triggered the activation of the pro-apoptotic caspase- 3 only after a long exposure. Conversely, low Doc concentrations induced a less evident downregulation of pMEK, an upregulation of Mcl-1 at the longest washout times, a clear increase in p21 expression, and a slight increase in the active form of caspase-3. Following the synergistic drug sequence used in our study, pMEK and Mcl-1 expression strongly decreased and p21 expression was slightly downsized, whereas activated caspase- 3 showed early and marked upregulation. These results suggest that treatment with low Doc concentrations activates apoptotic processes, which, however, may not be completed due to the concomitant triggering of pMEK-, Mcl-1- and p21-mediated survival pathways. Conversely, Zol seems to induce apoptosis and downregulate Doc-elicited anti-apoptotic mechanisms, bringing to an end the cell death processes initiated by the taxane.

Targeting pathways that converge on complementary signalling cascades is a strategy worthy of being exploited $[33,34]$. In agreement with this principle, our results demonstrate that simultaneous MEK and Mcl-1 inhibition induced by Zol, together with Doc-triggered apoptosis, could be key objectives in the treatment of hormone-sensitive prostate cancer.

The data reported in the present paper confirm those from other preclinical studies on the efficacy of Zol and Doc-
Zol combinations $[4,20,21]$ in the treatment of prostate cancer cells. They also highlight the importance of the schedule evaluated in hormone-sensitive cells using concentrations and exposures that could potentially occur in a clinical setting. Furthermore, considering the metastatic origin of the LNCaP cell line, our treatment option could also prove valuable in the management of hormone-sensitive metastatic cancer and in preventing the development of bone metastases regardless of hormone deprivation conditions, as suggested by Saad et al. [5].

\section{Conclusion}

In conclusion, although further research is needed to widen our knowledge of the mechanisms underlying the cytotoxic synergistic interaction and to explore other drug schedules, the results from the present study suggest that, under androgen deprivation conditions, low Doc doses in concomitance with and followed by Zol could be a potentially useful first-line treatment for hormone-sensitive prostate cancer. This schedule would seem to be capable of reducing the tumor cell population and of rapidly eradicating hormone-resistant cells present in hormoneresponsive tumors, without compromising the use of conventional-dose Doc.

\section{Abbreviations}

Doc: Docetaxel; Zol: Zoledronic acid; SRB: Sulforhodamine B; OP: Optical density; RI: R index; LC: Lethal concentration.

\section{Competing interests}

The authors declare that they have no competing interests.

\section{Authors' contributions}

FF was responsible for study design, data analysis, and drafting the manuscript. WZ, DA and RS participated in the study design and acted as scientific advisors. FF, GB, SC, PU, IV and AT performed the in vitro experiments. All authors read and approved the final manuscript.

\section{Acknowledgements}

The authors wish to thank Gráinne Tierney for editing the manuscript. Supported by the Italian Ministry of Health (Ricerca Finalizzata - Progetto Globale Prostata 2005-2007).

\section{References}

I. Pienta KJ, Smith DC: Advances in prostate cancer chemotherapy: a new era begins. CA Cancer J Clin 2005, 55:300-318.

2. Petrylak DP, Tangen CM, Hussain MH, Lara PN Jr, Jones JA, Taplin ME, Burch PA, Berry D, Moinpour C, Kohli M, Benson MC, Small EJ, Raghavan D, Crawford ED: Docetaxel and estramustine compared with mitoxantrone and prednisone for advanced refractory prostate cancer. N Engl J Med 2004, 35 I:I5 I3-I520.

3. Tannock IF, de Wit R, Berry WR, Horti J, Pluzanska A, Chi KN, Oudard S, Théodore C, James ND, Turesson I, Rosenthal MA, Eisenberger MA, TAX 327 Investigators: Docetaxel plus prednisone or mitoxantrone plus prednisone for advanced prostate cancer. N Engl J Med 2004, 35 I: |502-1512. 
4. Brubaker KD, Brown LG, Vessella RL, Corey E: Administration of zoledronic acid enhances the effects of docetaxel on growth of prostate cancer in the bone environment. BMC Cancer 2006, 6:15.

5. Saad F, McKiernan J, Eastham J: Rationale for zoledronic acid therapy in men with hormone-sensitive prostate cancer with or without bone metastasis. Urol Oncol 2006, 24:4-12

6. Carey AM, Pramanik R, Nicholson LJ, Dew TK, Martin FL, Muir GH, Morris JD: Ras-MEK-ERK signaling cascade regulates androgen receptor element-inducible gene transcription and DNA synthesis in prostate cancer cells. Int J Cancer 2007, 121:520-527.

7. McCubrey JA, Steelman LS, Chappell WH, Abrams SL, Wong EW, Chang F, Lehmann B, Terrian DM, Milella M, Tafuri A, Stivala F, Libra M, Basecke J, Evangelisti C, Martelli AM, Franklin RA: Roles of the Raf/MEK/ERK pathway in cell growth, malignant transformation and drug resistance. Biochim Biophys Acta 2007, I773:1263-1284.

8. Wang YF, Jiang CC, Kiejda KA, Gillespie S, Zhang XD, Hersey P: Apoptosis induction in human melanoma cells by inhibition of MEK is caspase-independent and mediated by the $\mathrm{Bcl}-2$ family members PUMA, Bim, and Mcl-I. Clin Cancer Res 2007, 1 3:4934-4942.

9. Boucher MJ, Morisset J, Vachon PH, Reed JC, Lainé J, Rivard N: MEK/ ERK signaling pathway regulates the expression of $\mathrm{Bcl}-2, \mathrm{Bcl}-$ $X(L)$, and $\mathrm{Mcl}-\mathrm{I}$ and promotes survival of human pancreatic cancer cells. J Cell Biochem 2000, 79:355-369.

10. Krajewska M, Krajewski S, Epstein JI, Shabaik A, Sauvageot J, Song K, Kitada S, Reed JC: Immunohistochemical analysis of bcl-2, bax, bcl-X, and mcl-I expression in prostate cancers. Am J Pathol 1996, I 48: I567-I576.

II. Royuela M, Arenas MI, Bethencourt FR, Sánchez-Chapado M, Fraile B, Paniagua R: Regulation of proliferation/apoptosis equilibrium by mitogen-activated protein kinases in normal, hyperplastic, and carcinomatous human prostate. Hum Pathol 2002, 33:299-306.

12. Royuela M, Arenas MI, Bethencourt FR, Sánchez-Chapado M, Fraile B, Paniagua R: Immunoexpressions of p2 I, Rb, mcl-I and bad gene products in normal, hyperplastic and carcinomatous human prostates. Eur Cytokine Netw 200 I, I 2:654-663.

13. Cavarretta IT, Neuwirt H, Untergasser G, Moser PL, Zaki MH, Steiner H, Rumpold H, Fuchs D, Hobisch A, Nemeth JA, Culig Z: The antiapoptotic effect of IL-6 autocrine loop in a cellular model of advanced prostate cancer is mediated by Mcl-I. Oncogene 2007, 26:2822-2832.

14. Skehan P, Storeng R, Scudiero D, Monks A, McMahon J, Vistica D, Warren JT, Bokesch H, Kenney S, Boyd MR: New colorimetric cytotoxicity assay for anticancer-drug screening. J Natl Cancer Inst 1990, 82: | 107-I|| 2.

15. Monks A, Scudiero D, Skehan P, Shoemaker R, Paull K, Vistica D, Hose C, Langley J, Cronise P, Vaigro-Wolff A, Gray-Goodrich M, Campbell H, Mayo J, Boyd M: Feasibility of a high-flux anticancer drug screen using a diverse panel of cultured human tumor cell lines. J Natl Cancer Inst I99I, 83:757-766.

16. Kern DH, Morgan CR, Hildebrand-Zanki SU: In vitro pharmacodynamics of I-beta-D-arabinofuranosylcytosine: synergy of antitumor activity with cis-diamminedichloroplatinum(II). Cancer Res 1988, 48: I 17-121.

17. Romanelli S, Perego P, Pratesi G, Carenini N, Tortoreto M, Zunino F: In vitro and in vivo interaction between cisplatin and topotecan in ovarian carcinoma systems. Cancer Chemother Pharmacol 1998, 41:385-390.

18. Herbst RS, Khuri FR: Mode of action of docetaxel - a basis for combination with novel anticancer agents. Cancer Treat Rev 2003, 29:407-4I5.

19. Corey E, Brown LG, Quinn JE, Poot M, Roudier MP, Higano CS, Vessella RL: Zoledronic acid exhibits inhibitory effects on osteoblastic and osteolytic metastases of prostate cancer. Clin Cancer Res 2003, 9:295-306.

20. Ullén A, Lennartsson L, Harmenberg U, Hjelm-Eriksson M, Kälkner KM, Lennernäs B, Nilsson S: Additive/synergistic antitumoral effects on prostate cancer cells in vitro following treatment with a combination of docetaxel and zoledronic acid. Acta Oncol 2005, 44:644-650.

21. Morgan C, Lewis PD, Jones RM, Bertelli G, Thomas GA, Leonard RC: The in vitro anti-tumour activity of zoledronic acid and docetaxel at clinically achievable concentrations in prostate cancer. Acta Oncol 2007, 6:669-677.

22. Extra JM, Rousseau F, Bruno R, Clavel M, Le Bail N, Marty M: Phase I and pharmacokinetic study of Taxotere (RP 56976; NSC 628503) given as a short intravenous infusion. Cancer Res 1993, 53:1037-1042.

23. Brunsvig PF, Andersen A, Aamdal S, Kristensen V, Olsen H: Pharmacokinetic analysis of two different docetaxel dose levels in patients with non-small cell lung cancer treated with docetaxel as monotherapy or with concurrent radiotherapy. BMC Cancer 2007, 7: 197.

24. LoRusso PM, Jones SF, Koch KM, Arya N, Fleming RA, Loftiss J, Pandite L, Gadgeel S, Weber BL, Burris HA 3rd: Phase I and pharmacokinetic study of lapatinib and docetaxel in patients with advanced cancer. J Clin Oncol 2008, 26:305 I-3056.

25. Dumon JC, Journé F, Kheddoumi N, Lagneaux L, Body JJ: Cytostatic and apoptotic effects of bisphosphonates on prostate cancer cells. Eur Urol 2004, 45:52I-528.

26. Oades GM, Senaratne SG, Clarke IA, Kirby RS, Colston KW: Nitrogen containing bisphosphonates induce apoptosis and inhibit the mevalonate pathway, impairing Ras membrane localization in prostate cancer cells. J Urol 2003, 170:246-252.

27. Caraglia M, Santini D, Marra M, Vincenzi B, Tonini G, Budillon A Emerging anti-cancer molecular mechanisms of aminobisphosphonates. Endocr Relat Cancer 2006, 13:7-26.

28. Kimmel DB: Mechanism of action, pharmacokinetic and pharmacodynamic profile, and clinical applications of nitrogencontaining bisphosphonates. J Dent Res 2007, 86: 1022-1033.

29. Fabbri F, Brigliadori G, Ulivi P, Tesei A, Vannini I, Rosetti M, Bravaccini S, Amadori D, Bolla M, Zoli W: Pro-apoptotic effect of a nitric oxide-donating NSAID, NCX on bladder carcinoma cells. Apoptosis 4040, 10:1095-1103.

30. Fabbri F, Carloni S, Brigliadori G, Zoli W, Lapalombella R, Marini M: Sequential events of apoptosis involving docetaxel, a microtubule-interfering agent: a cytometric study. BMC Cell Biol 2006, 7:6.

31. Sobel RE, Sadar MD: Cell lines used in prostate cancer research: a compendium of old and new lines - part I. J Urol 2005, 173:342-359.

32. Liu ZM, Chen GG, Ng EK, Leung WK, Sung JJ, Chung SC: Upregulation of heme oxygenase- $I$ and $\mathrm{p} 2 \mathrm{I}$ confers resistance to apoptosis in human gastric cancer cells. Oncogene 2004, 23:503-5।3

33. Faivre S, Djelloul S, Raymond E: New paradigms in anticancer therapy: targeting multiple signaling pathways with kinase inhibitors. Semin Oncol 2006, 33:407-420.

34. Legrier ME, Yang CP, Yan HG, Lopez-Barcons L, Keller SM, PérezSoler R, Horwitz SB, McDaid HM: Targeting protein translation in human non small cell lung cancer via combined MEK and mammalian target of rapamycin suppression. Cancer Res 2007, 67:11300-11308.

\section{Publish with Bio Med Central and every scientist can read your work free of charge}

"BioMed Central will be the most significant development for disseminating the results of biomedical research in our lifetime. "

Sir Paul Nurse, Cancer Research UK

Your research papers will be:

- available free of charge to the entire biomedical community

- peer reviewed and published immediately upon acceptance

- cited in PubMed and archived on PubMed Central

- yours - you keep the copyright
BioMedcentral 